\title{
Making Law: Small-Scale Trade and Corrupt Exceptions at the Vietnam-China Border
}

Kirsten W. Endres

\begin{abstract}
In Vietnam's postreform era, the proliferation of profiteering opportunities have, in addition to creating new forms of corruption, transmuted previously prevailing types of corrupt acts in multiple ways across different levels of state-society relations. Everyday corrupt practices have thus become an essential means of economic survival for many. Starting from the metaphorical framing of petty bribery as "making law," I propose the notion of what I term "corrupt exception" as a conceptual tool to explore the power dynamics of petty corruption between state agents and small-scale traders at the Vietnam-China border. Whereas bribery is felt by local traders to create better profit opportunities, the corrupt exception likewise pushes them into a de facto illegality where they remain subjected to arbitrary "lawmaking" and excluded from legal protection. I show that the metaphors employed by small-scale traders to negotiate complicit relationships with corrupt state officials both contest and reinforce the exercise of a localized form of sovereign power in a permanent state of corrupt exception in which "law" is "made" in exchange for bribes. [corruption, cross-border trade, metaphor, exception, sovereign power, Vietnam, Lào Cai City]
\end{abstract}

RESUMEN A través de los distintos niveles de las relaciones Estado-sociedad en la era post-reforma de Vietnam, la proliferación de oportunidades de beneficio ha transformado en múltiples maneras las formas de corrupción anteriormente prevalecientes, al tiempo que han surgido nuevos tipos de actos corruptos. Así, las prácticas cotidianas de corrupción han devenido un medio esencial de subsistencia económica para muchos. A través de la interpretación metafórica de la pequeña corrupción como "hacer ley," propongo el término "excepción corrupta" como una herramienta conceptual para explorar las dinámicas de poder de la pequeña corrupción en la frontera entre Vietnam y China. Al tiempo que el soborno es percibido por los comerciantes locales como una herramienta para crear mejores oportunidades de beneficio, la excepción corrupta los conduce a una ilegalidad de facto dentro de cuyo marco dichos comerciantes permanecen sujetos a un "hacer ley" arbitrario y, por lo tanto, los excluye de cualquier protección legal. En este artículo muestro que las metáforas utilizadas por los pequeños comerciantes para negociar una complicidad compartida con los oficiales estatales corruptos, desafían, al tiempo que refuerzan, el ejercicio de un poder soberano localizado en un permanente estado de excepción corrupta donde "la ley" es "hecha" en el intercambio de los sobornos. [corrupción, comercio transfronterizo, metáfora, excepción, poder soberano, Vietnam, Ciudad Lào Cai]

E very morning, scores of Vietnamese transporters and trader intermediaries gather at the Lào Cai-Hekou border gate and wait for the checkpoint to open at 7:00 a.m. sharp. Their role in directing the flow of goods from Chinese wholesalers and retailers in Hekou, Yunnan Province, to Lào Cai City on the Vietnamese side of the border is crucial (see 


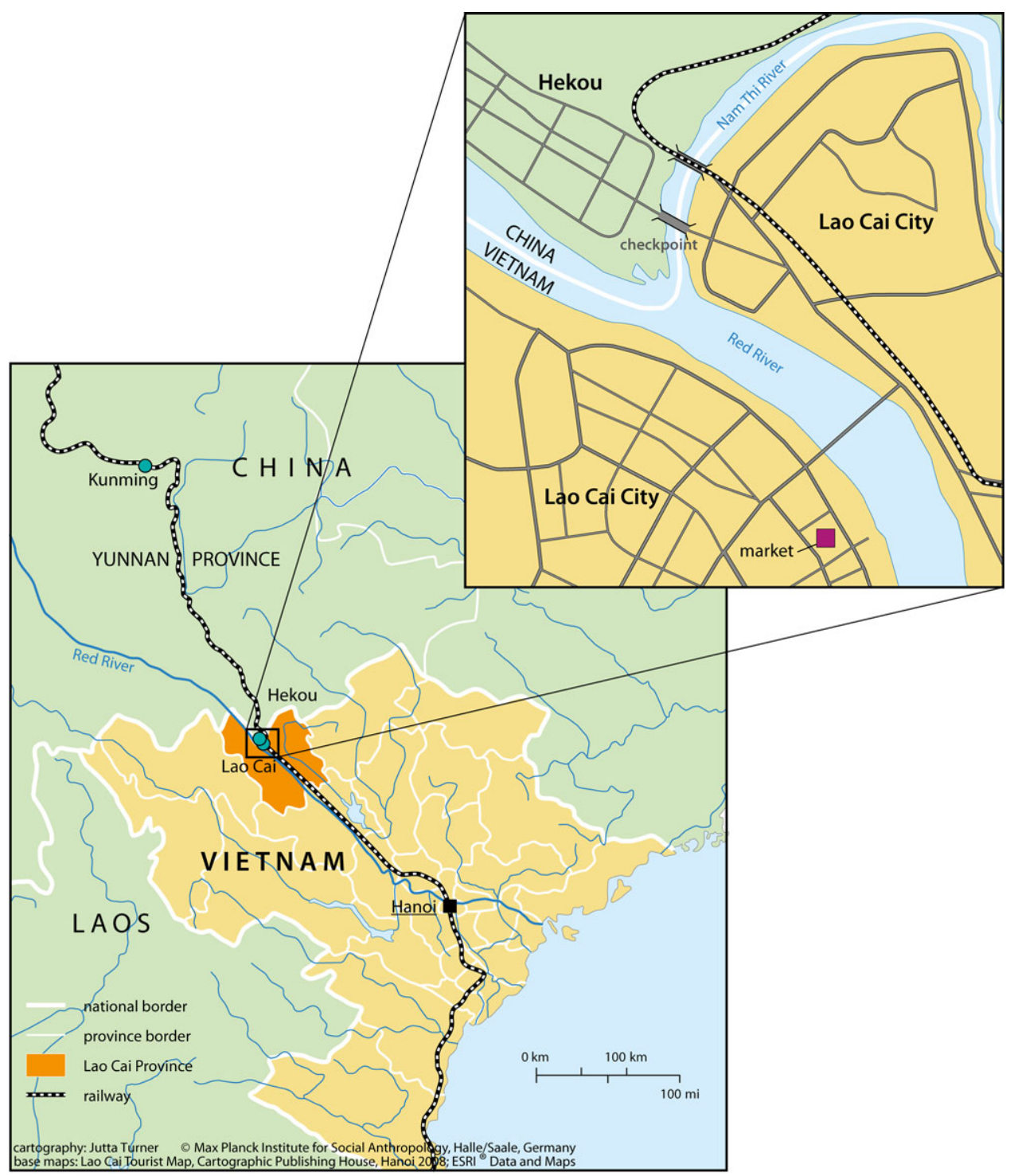

FIGURE 1. Map of northern Vietnam, with detail showing the location of the Lào Cai-Hekou international border gate.

Figure 1). One of these intermediaries, whom I shall call Mr. Hung, specializes in the supply of various goods to Lào Cai-based market vendors. As a local resident, Mr. Hưng holds a special border-crossing permit that entitles him to the duty-free import of Chinese-produced goods into Vietnam up to a maximum value of two million đồng (around \$95) per person per day per load. His daily trading volume, however, exceeds this amount by far. Moreover, some of his goods do not comply with current quality and regulatory requirements. To reduce import costs and avoid closer scrutiny, Hưng has an arrangement with a set of customs officials on a 500,000 đồng (around \$24) per month basis and schedules his trips to match their hours of duty. Once Hung has passed the border gate, he may be pounced upon by a mobile patrol of the market control department in charge of trade law enforcement. For a monthly "fee" of 400,000 đồng (around \$19) to the market control team, Hưng does not have to worry much about such encounters. According to the good-humored middleman, these arrangements are necessary for him and the market vendors he supplies to stay profitable in their business. "Making law [làm luật; i.e., negotiating a bribe] with customs officials and evading [import] tariffs are essential, otherwise we couldn't make enough for a living," he says (conversation with author, September 6, 2012).

In this article, I examine how small-scale traders at the Lào Cai-Hekou border gate negotiate their cross-border trading opportunities with customs officials and other lawenforcing state agents. Through a detailed study of two corruption episodes at my major field site, a large staterun market in Lào Cai City, I illustrate that corruption encounters take place in two different directions: in the one described above, a transgressor of the law (in this case, the trader) negotiates a bribe to bypass a legal restriction or avoid being fined for its violation; in the other, a law enforcement official extorts a bribe from a (real or alleged) 
transgressor in return for not applying the law. In both cases, the authority to grant an unlawful exception to the legal provisions in place ultimately rests with those whose actual task it is to enforce compliance with the law. In their everyday encounters with borderland traders, local state officials thus assume a localized form of sovereign authority, defined by the ability to decide whether to enforce the law or to declare an exception.

I suggest that the juridical concept of exception provides a useful conceptual tool to explore the power dynamics of petty corruption at the Vietnam-China border. This approach builds on the premise that the bribe arrangements of small-scale traders like Mr. Hưng are intimately bound up with the state official's assumed sovereign power to decide on an unlawful exception to the legal provisions that regulate cross-border trade. I define this exception as "corrupt" in the literal sense that it is granted in exchange for a bribe. The metaphorical framing of petty corruption as "making law" (làm luật) adds an intriguing twist to this notion. As Giorgio Agamben (1995:26) notes, "The law has a regulative character and is a 'rule' not because it commands and proscribes, but because it must first of all create the sphere of its own reference in real life and make that reference regular." This perspective holds that lawmaking is preceded and determined by an exceptional (and most often undesirable) situation or fact that continues to remain unregulated by law unless it is included into the legal order by its very exclusion from the normal sphere of life. It is in this light that Agamben (1995:26) sees the exception as "the originary form of law." Làm luạt, however, in its euphemistic sense of negotiating a bribe arrangement, is not preceded by a situation unregulated by law. Rather, it blurs the distinction between the already existing legal framework and the transgressive fact by establishing an unlawful, corrupt exception from the law in the name of law.

Anthropologists have analyzed the intricacies of illegal and semilegal flows of goods and people across national borders from a variety of perspectives: as an expression of resistance to states that fail to provide their citizens with sustainable employment opportunities (MacGaffey et al. 1991), as a subversive economy that imposes practical limits on the exercise of state power (Donnan and Wilson 1999), as a collaborative form of trade regulation governed by practical norms and mutual understanding between state agents and local traders (Titeca and de Herdt 2010; Walker 1999), or as a way for traders to challenge and reinterpret neoliberal logics of free trade to their own advantage (Galemba 2012). While each of these perspectives offers a valid way of understanding the particularities of borderland economies and the wider social, moral, and political processes in which they are embedded, the exigencies of systemic corruption in the broader context of Vietnam's socialist-oriented market economy require a view from a somewhat different perspective.
Largely inspired by Agamben's work (1995, 2005), the concept of "the exception" has drawn much scholarly attention in the past decade, particularly in studies on neoliberal governmentality and citizenship regimes. In her book Neoliberalism as Exception (2006), Aihwa Ong deploys the exception to examine neoliberal strategies of governing in East and Southeast Asia that rely on the creation of "differently administered spaces of 'graduated' or 'variegated sovereignty" (Ong 2006:7), such as free trade zones in border areas and other economic and administrative enclaves. Whereas the exception is most often associated with the suspension of basic citizen rights and the reduction of people to "bare life” (Agamben 1995), Ong's neoliberal zones of exception instead offer special economic opportunities to certain segments of the population while excluding others. In countries in which neoliberalism itself is not the norm, these logics of inclusion and exclusion demarcate the boundaries between what Ong calls "neoliberalism as exception" and "exceptions to neoliberalism" (Ong 2006:5).

In contrast, the notion of what I term "corrupt exception" shifts attention to certain spaces of overlap between inclusion (into the neoliberal logics of economic selfadvancement) and exclusion (from legal protection and, more generally, political participation) in a state in which corruption has become the norm rather than the exception. On the one hand, the corrupt exception at the Lào CaiHekou border gate is seen by many Vietnamese small-scale traders as essential for deriving a profitable income from cross-border trade and trade-related services. Oftentimes, traders construe their complicit arrangements with corrupt officials as benevolent exchange relationships from which they ultimately receive more than they give, and notions of hardship and family burdens are employed to elicit compassion and urge state officials to apply the law with reason and sentiment. Yet, on the other hand, the corrupt exception also constitutes a space of illegality in which the law is broken twice in the name of the law: first by the transgressor who violates the (real or alleged) law and then by the official who accepts or extorts a bribe in return for not applying the law. Through their inclusion into this space of illegal opportunity, the corrupt exception likewise excludes cross-border traders from legal protection in their economic pursuits and subjects them to predatory law-enforcement practices. Routine raids for substandard or prohibited goods are met with much resentment and moral outrage, as they are primarily (and most often correctly) seen as a pretext for negotiating the conditions of exchange required for the corrupt exception to apply.

Corruption can hence also be understood as "a form of exchange: a polysemous and multi-stranded relationship and part of the way in which individuals connect with the state" (Shore and Haller 2005:7). If all forms of exchange are ultimately embedded in social and power relations and moral economies, then corruption, too, is subject to continuous processes of embedding and re-embedding in the 
changing societal, economic, and political contexts in which it occurs. Besides addressing the particular social and cultural complexities involved, an anthropological inquiry into the practices and discourses of corruption may further shed light on how, as Akhil Gupta (2005:175) suggests, "people imagine the state to be, what state actions are considered legitimate, and how ideas of rights of citizens and subjects are constituted." What Gupta does not take into account, however, is that citizens may also be, to some extent, co-opted into the wider political economy of systemic corruption. I argue that metaphors and other figures of speech play a crucial role in mediating such processes of embedding and co-opting. As cognitive tools "rooted in the cultural categories within which speakers construct their conversations" (Ben-Amos 1999:152; see also Lakoff and Johnson 1980), metaphors not only frame and shape human (self-)perception and social experience but also harbor the potential to transmit social commentary and political criticism. My findings show that although the growth of systemic corruption in Vietnam has transformed the overall ways in which Vietnamese citizens imagine and experience the state, the tropes, analogies, and metaphors employed by small-scale traders at the Vietnam-China border to negotiate complicit exchange relationships with state officials simultaneously contest and reinforce the exercise of assumed sovereign power in local sites of corrupt exception.

\section{NEOLIBERAL REFORMS, CORRUPTION, AND THE SECRET OF LAW}

Corruption has for a long time been most closely associated with underdevelopment and poor governance in the non-Western world. Since the end of the Cold War, however, the spread of neoliberal principles of market deregulation and privatization has spurred, contrary to the promises of dominant neoliberal perspectives, unprecedented forms and scales of corruption across the globe (Brown and Cloke 2004). Vietnam's shift from a centrally planned economy to a socialist-oriented market economy has had similar effects, and ordinary citizens feel increasingly disenchanted by the degree to which corruption in its manifold manifestations has come to permeate their lives. ${ }^{1}$ An escalating series of high-profile scandals revealing the close ties between the political elite and private business interests contributed not only to an upsurge in discontent among the general population (MacLean 2012) but also to an increased readiness to question the integrity of the political system and voice offthe-record anger, such as the market woman who whispered into my ear, "I just hate the system (chế độ). It is corrupt all the way through!" (conversation with author, September $15,2012) .^{2}$ The rise of corruption as a spiraling systemic phenomenon has apparently eroded respect for the state leadership to such a degree that expressions of discontent have become much bolder than in the past. ${ }^{3}$

Corruption is, of course, nothing new to Vietnam. Besides the most common contemporary terms for corruption and bribery, tham nhũng and hối lộ, the Vietnamese language is rich in metaphorical expressions denoting a variety of corruption-related practices in different historical and social class contexts. The phrase "the silver bullion pierces the paper document" [nén bạc đâm toạc tờ giấy], for example, dates back to ancient times and indicates a bribe paid to influence a mandarin official to revoke a decree or an edict. If the latter was a member of the petitioner's lineage, the mandarin official would even have been morally obliged to generously grant favors and privileges to his relative, true to the adage "one man becomes a mandarin, his entire lineage benefits" [một người làm quan, cả họ được nhở]. Under French colonial rule (1884-1945), corruption and nepotism among mandarins and local notables became ever more pervasive (Gillespie 2002:174). The common people's attitude toward greedy and corrupt officials was encapsulated in a proverb that is still popularly used today: "At night we are robbed by bandits and at daytime by the mandarins" [cướp đêm là giạcc, cướp ngày là quan].

During the so-called subsidy period from 1975-1986, bribing and gift giving was frequently referred to as lo lót ("taking care of the lining"), in the sense of feathering someone's nest to generate favorable conditions for oneself. Significant segments of the Vietnamese population, including traders and entrepreneurs, apparently "survived decades of central planning and official suppression by co-opting, corrupting and evading state regulators" (Gillespie 2009:248; MacLean 2008). In southern Vietnam, similar practices evolved during the cooperativization of private trade in the 1980s. Ann Marie Leshkowich (2008:23) relates that traders at Bến Thành market (Hồ Chí Minh City) "today joke that one of the great ironies of the central government's cooperative system was that the primary cooperation it fostered was between traders and market management in outwitting the state."

As elsewhere in socialist economies, elaborate networks of social relations - based on mutual obligation and reciprocity and nurtured by the exchange of gifts and favorsplayed an important role in facilitating access to otherwise scarce goods. ${ }^{4}$ After economic reform, such networks - as well as corruption - not only became more or less "regular solutions to problems of exchange left unsolved by the rule of law and administrative reforms" (Abrami 2002:2) but gradually evolved into a system of rule that some scholars classify as neopatrimonial. In such a system, public offices become commodities that provide ample opportunities to earn back one's own investment by way of misappropriating public resources and extracting rents from below, parts of which are channeled upward in return for further patronage from higher levels of state bureaucracy. "By paying bribes we feed (nuôi sông) the tax inspectors and customs officials, and these guys in turn feed other guys," Mr. Hưng explains, referring to the elaborate patronage networks through which positions in the state sector have come to be secured in present-day Vietnam, "because if you want to work in a lucrative place 
like this [the Lào Cai-Hekou border gate], you have to spend huge sums to pay your way in" (conversation with author, August 27, 2012). In his opinion, it is impossible to fight the pervasiveness of corruption in contemporary Vietnam. This, he reasons, is "the dark side of Vietnamese society."

Another rich field of profit-seeking opportunities was opened up by the privatization of state-owned businesses and assets. ${ }^{5}$ As in China (Sun 2004:203), the distribution of such opportunities for enrichment and access to power is highly uneven across social groups and regions in Vietnam. Corruption and its distributional effects thus contributed to the growing sense of "exasperated distress" (Harms 2012:739) among the wider population over the blatant discrepancies between the Communist Party's claim of advocating social justice and equality and the reality of economic insecurity, political powerlessness, and an ever-widening divide between rich and poor. Yet as David Smith (2007:5) has pointed out in the case of Nigeria, ordinary citizens "can be, paradoxically, active participants in the social reproduction of corruption even as they are also its primary victims and principal critics."

It was allegedly not until the early 1990s that certain forms of corruption became couched in terms of làm luật. ${ }^{6}$ John Gillespie (2001:10) contends that making law refers to "the arrogation of power by officials to resolve issues not directly addressed by formal law," which then "has the positive connotation of manufacturing local solutions to centrally imposed problems and the negative implication of inventing laws to extract rents." My research, however, shows that in its current usage the term more likely refers to the renegotiation of actually existing legal prescriptions. Perhaps the most commonplace làm luạt situation involves the negotiation of an on-the-spot fine between the traffic police and a traffic rules violator, such as when a motorcyclist is caught turning into the wrong lane or fails to present a valid driver's license during a routine traffic stop. Smugglers of contraband make law with relevant local authorities before carrying their wares across the border. Larger illegal trade networks, for example, in the logging and timber industry, may even use bribe brokers, called người làm luật, to ensure that each truckload of wood enjoys a smooth passage through various road checkpoints along the way (Sikor and To 2011:695). Depending on the nature, amount, and size of goods smuggled on the chosen route, more or less elaborate arrangements need to be made. The term therefore seems to imply a certain agency on the part of the bribers in making laws that suit their needs. Conversely, however, làm luật also refers to the extortion of bribes from offenders in return for not applying the law.

Unraveling the dimensions of the metaphor therefore requires a brief review of the Vietnamese political and legal system. Vietnam is a one-party state ruled by the Communist Party of Vietnam, whose role as the leading force in state and society remains firmly enshrined in the constitution. The National Assembly, designated as the highest organ of state power and representative of the people, is vested with the sole constitutional and legislative authority. However, as with legislative processes elsewhere in the world, the reality is more complicated. During the pre-reform era, party resolutions and directives, though not technically considered law, in fact had a prelegislative function and thus formed the "skeleton of national legislation" during the socialist period (Dang and Beresford 1998:71-79). These resolutions, often mapped out in opaque propagandistic prose, were then basically left to interpretation at the hands of lower-level authorities, which allowed for a limited but relevant scope of flexibility in (technically illegal) local adaptation and experimentation (Kerkvliet 2005).

Since the introduction of đổi mới ("change to the new") in the 1980s, the legal system has undergone profound changes aimed at establishing the rule of law and improving government transparency. This entails that laws are now drafted by the government that is also authorized to issue further subordinate legislation such as detailed regulations, bylaws, and guidelines. Adding to the complexity of the legislative process, law-making authority is not limited to the central level of state administration but also takes place at the provincial, district, and commune level. Thus, "each level can promulgate subordinate legislation and from a constitutional perspective act as a lawmaker" (Gillespie 2008:681). The vertical distribution of law-making authority has not only led to a proliferation of decrees, ordinances, directives, and circulars but also provided its enforcers and transgressors (who often coincide with each other) with new avenues for corruption, an effect that Xiaobo Lü (2000:172) sees as an "unintended result of institutionalization efforts" in the case of China. In Vietnam, the coining of làm luật as an idiomatic term for corruption underscores Walter Benjamin's contention that "law-making is power making, and, to that extent, an immediate manifestation of violence" (Comaroff and Comaroff 2006:35). The "secret of the law," as Gerhard Anders and Monique Nuijten (2007:12) argue, is that the possibility of its violation is already "inscribed into the law as hidden possibility." In sites of corrupt exception, this hidden possibility emerges as a rule and generates a form of localized sovereign power that wields authority by violating the law, or, as Jakob Rigi (2012:81) puts it, by "counterfeiting legality."

\section{CHALLENGES OF ETHNOGRAPHY IN A SITE OF EXCEPTION}

Lào Cai's history as an embattled trading post located on Vietnam's frontier with China is characterized by major disruptions associated with banditry and ethnic rivalry in its ancient days, followed by French colonialism (1889-1954), socialist transformation, and the experience of war. When Chinese troops invaded northern Vietnam in February 1979, Lào Cai was shelled to ruins and its migrant ethnic majority residents - most of whom had hailed from the lowlands in the early 1960s - were urged to return to their places of origin. Following the normalization of Sino-Vietnamese relations in the late 1980 s, border trade gradually resumed. 


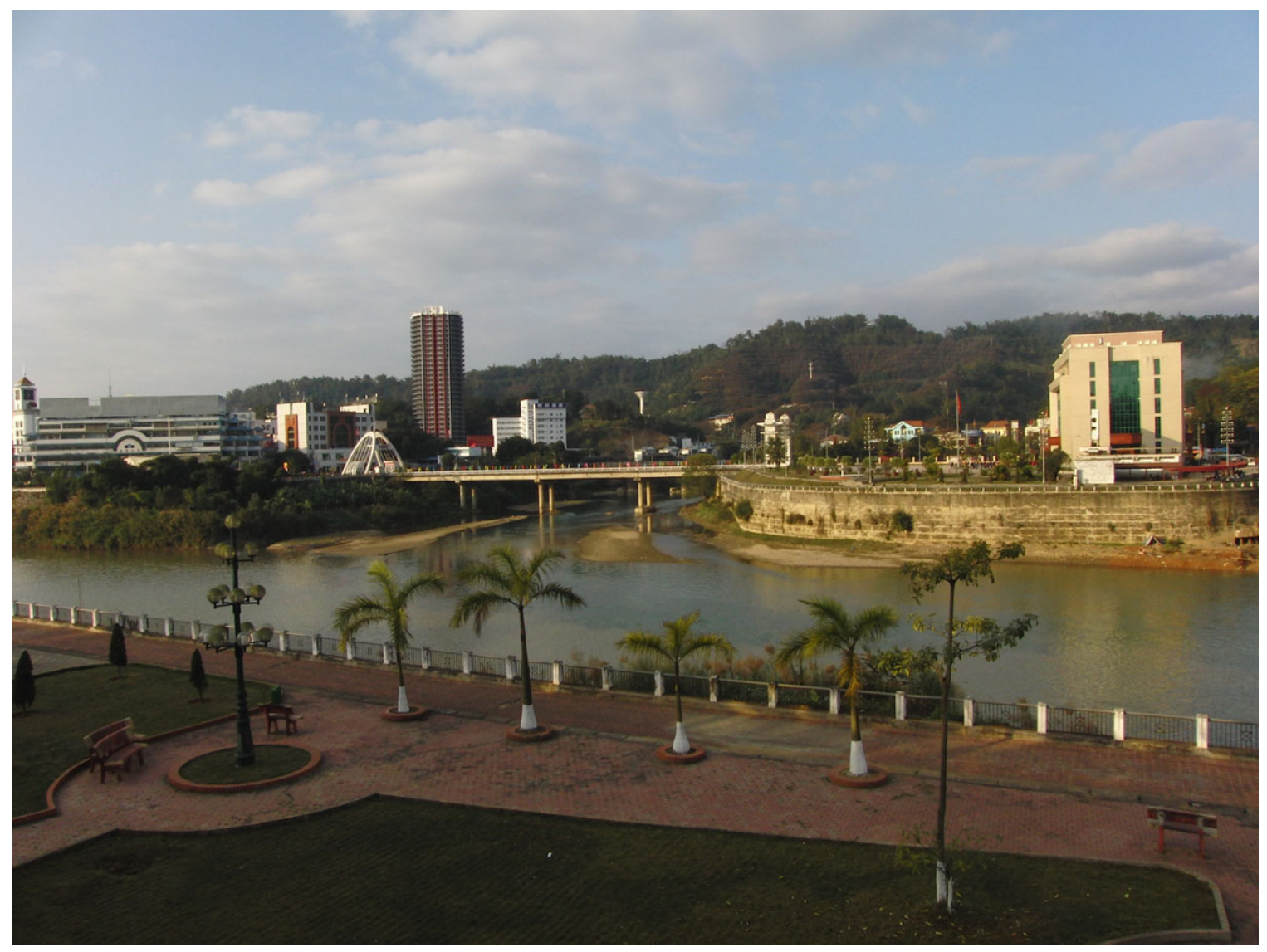

FIGURE 2. View across the Red River toward Hồ Kiều Bridge, which links Lào Cai City, Vietnam, with the Chinese city of Hekou, Yunnan. (Photo by the author, February 2011)

On either side of the frontier, the emerging border economic zones drew, in addition to evacuation returnees, substantial numbers of spontaneous migrants from economically disadvantaged regions in search of work and a better life. Cross-border trade, on the one hand, was seen by the Vietnamese state as an important opportunity for the economic development of the border region that would create new (or better) livelihood options for both the ethnic Kinh majority and for the ethnic minority population in the highlands. ${ }^{7}$ On the other hand, the competitive advantage of China's economic growth soon led to an unfavorable trade balance for Vietnam, thus calling for tighter regulations and restrictions to keep the flow of Chinese goods from turning into a torrent that would undermine Vietnam's national industry.

Lào Cai City stretches out to the south from the junction of the Red River and Nậm Thi River and borders the Chinese town of Hekou, Yunnan province. A bridge across Nậm Thi River connects the twin towns and currently serves as an international border crossing for pedestrians and small transportation vehicles (see Figure 2). Located south of the river junction that marks the border, the major city market is only a kilometer away from the bridge that serves as Lào Cai's gateway to China. ${ }^{8}$ I chose Lào Cai market as my primary field site for investigating the complex dy- namics of social relations and exchanges that facilitate the participation of small-scale Kinh (ethnic majority) market traders in cross-border economic activity. As an important economic resource for borderlanders in many parts of the world, small-scale cross-border trade inevitably makes use of various means and skills to circumvent the restrictions imposed on it (Bruns and Miggelbrink 2012; Wagner 2011). I was thus prepared to hear not only about ways of fostering trustful relations with trading partners and customers but also about bribes paid to customs officers, support from patronage, and the exchange of gifts for favors to secure advantages in the market environment. The outright issue of corruption, however, was not part of my research agendait would have raised the concern of those for whom the mere presence of a foreign anthropologist in town already posed a potential threat to border security. My official research permission was therefore limited to Lào Cai's largest marketplace, and this is where my assistant and I conducted the bulk of research from October 2010 to March 2011 and in August and September of 2012.

During peak hours, vendors were inevitably busy with attracting customers to their stalls, and much of our daily routine consisted of hanging out in the market's various sections; observing the ebb and flow of trading activities and social interactions with fellow vendors, market 
administration personnel, and law-enforcement officials; and engaging in casual conversations and idle gossip with vendors during the less busy hours. Occasionally, however, we also ventured out to both sides of the border to watch the loading and unloading of goods, observe custom procedures, and to chat, as inconspicuously as possible, with transporters and trader intermediaries who traverse the border on a regular basis, some even several times per day. ${ }^{9}$ In contrast to international airports, where encounters between travelers and custom officials are more fleeting in nature (Chalfin 2008), the wielding of sovereign authority by Lào Cai-Hekou border gate officials takes place in the much more intimate space of shared knowledge and practices that defines "communities of complicity" (Steinmüller 2010). Yet the notion of "cultural intimacy" (Herzfeld 2005) does not account sufficiently for the sensitivities that determine the cautious attitude of Vietnamese state officials toward foreign outsiders who, it is feared, may tarnish the image of Vietnam by exposing its ugly sides. In a site of corrupt exception, this includes the possibility of witnessing (as I did on several occasions) the rather common use of extralegal forms of law enforcement, such as harassment, intimidation, and sometimes even outright violence.

Sites of corrupt exception are thus inevitably shrouded in an air of secrecy. Some of the secrets that abound in Lào Cai have taken the literally concrete form of opulent buildings towering high above their surroundings. My inquiries as to who were their owners were almost inevitably met with an indication that pointed to the involvement of some higher-level state official_- or, rather, their relatives (con cháu các cụ cả; i.e., the grandchildren and nephews of senior elders). "They enjoy the elders' protection and can thus freely engage in [the pursuit of illicit wealth]," one of my more straightforward interlocutors (whom I shall call Dũng) claimed. "That's why there are so many luxurious villas here, although many rich people are cautious - they maintain a simple lifestyle in Lào Cai and buy houses in Hanoi instead" (field notes, August 30, 2012). Moreover, I was told that the contraband smuggled through the Lào Cai-Hekou border gate is really only the tip of the iceberg. The big smuggling allegedly takes place elsewhere, at night. "Nighttime is the time when the black society (xã hội đen; i.e., organized criminals) becomes active,” Dũng continued, "and the majority of these guys are under the patronage of some big man. It's only drugs and human traffickers who get caught. Everything else may move freely (tự do).”

Considering the massive scale of corrupt enrichment that takes place at higher levels of the unholy confluence of clientelistic power mechanisms and capitalist opportunities to profit, it is certainly not unreasonable to think that there is some truth to such allegations and rumors. Yet only a few of my interlocutors addressed the issue of corruption explicitly. Those who did provided valuable clues for the present analysis - an analysis that, despite being limited in scope and perspective to the experiences, practices, and attitudes of small-scale traders at the margins of the Vietnamese state, hopes to shed light on the overall ways in which petty corruption between citizens and state officials manifests and perpetuates itself in contemporary Vietnamese society. In the following sections, I provide an ethnographic account of how small-scale traders frame and enact relationships of complicity in the spaces of exception in which corrupt encounters between themselves and state officials take place. As I shall demonstrate, these relationships are shaped in a dialectic tension between the degree of illegality or illegitimacy perceived by either side and the degree of reason and sentiment applied in the act of corruption.

\section{COMPASSIONATE COMPLICITY}

One chilly morning in early January 2011, a team of inspectors from the provincial Department for Standards, Metrology and Quality arrived at the electronics section of Lào Cai market. Mrs. Hà, a stout vendor in her forties who runs a stall selling rice-cookers and other electric household appliances, had just finished arranging her merchandise on the shelves when the inspectors randomly singled out her stall for close examination and started rummaging through the mostly Chinese-produced goods on display. Mrs. Hà's puzzled expression quickly turned to one of indignation. "For heaven's sake!" she exclaimed, "All of our goods are floating goods, across-the-river goods, just go ahead and confiscate them from each and every stall; here at the border we're all smugglers and tax dodgers!" A male vendor from a neighboring stall chimed in with a pleading voice, "Please sympathize with us, we are market folks suffering from famine, please exempt us so that our kids have a bowl of rice! If we don't sell these goods we won't have any customers, they like buying cheap stuff. In many months we suffer losses, in others we just make enough to survive!" Lowering his voice again, he continued his cell phone conversation. "We're having a quality inspection here, now we'll have to bargain and make law; sure it won't be a problem." After about an hour of agitated suspense, bureaucratic formalities, and negotiations, one of the inspectors explained, "The law needs to be implemented; you [vendors] need to accept that. Merchandise that doesn't comply with quality standards either has to be confiscated or charged with a fine of at least ten percent of its value. In this case this would probably mean ten million đồng, [around \$475]. However, we will only charge one million, because people in the border area could not live by trade if we imposed the law properly. The annual inspection is just to remind you that there in fact is a law."

The above incident demands closer attention in the larger context of the everyday practices, social norms, and moral attitudes that inform Vietnamese small market trade. Mrs. Hà's cynical self-accusation ("we're all smugglers and tax dodgers!") captures, in a nutshell, a crucial aspect of the social stigma attached to traders and commerce. Historically (and in common with many other societies), trading had never been accorded a positive value but was seen as "an occupation of cheating and lying" (Malarney 1998:271). 
During the state-planned economy, private trade was considered unproductive and tolerated only as a means of survival without regard to "selfish" profit - although it was never entirely eliminated (Abrami 2002). In the two and a half decades since Vietnam's turn to a market economy "with socialist orientation," marketplaces and small-scale trade have become a ubiquitous, legitimate, and viable means of income for many. Yet the image of the dishonest trader has prevailed to this day in public opinion (Leshkowich 2011). Vendors are notoriously suspected of manipulating their weighing scales or yardsticks, of lying about the origins and quality of their goods, and of overcharging the unsavvy customer for the sake of higher profits. These accusations are not always unfounded and sometimes even openly admitted: "If we don't lie," a vendor of small souvenirs and cigarettes confided, "we cannot survive in the market" (conversation with author, September 1, 2012).

Mrs. Hà's outburst adds yet another dimension to this picture - that traders also cheat the government of tax revenue by smuggling goods across the river (or through the official border gate) from China. Her stall neighbor's plea to the quality inspectors for compassion ("we are market folks suffering from famine") does not refute this practice but, rather, provides a number of explanations for the traders' resort to fiscal fraud. Most explicitly, he mentions the customers' preference for cheap goods that doesn't allow the official tax and customs fees to be calculated into the prices. Moreover, he implies that market trade is not a highly profitable business in the first place but, rather, one that provides little more than mere subsistence - a bowl of rice for the children, so to speak. ${ }^{10}$ One key to this self-construction is certainly to be found in the dictates of popular morality according to which honest traders must keep their profit margins very small lest they would be accused of charging cutthroat prices. By emphasizing the smallness of their commercial endeavors and downplaying their success in the market economy, contemporary small traders perhaps primarily seek to shield themselves against all sorts of regulations that may cut further into their profits. Their self-description as unfortunate and pitiable market folks plagued by poor sales and meager profits, however, also entails a performative dimension - one that elicits the compassionate complicity of state authorities, in this case the quality inspectors. ${ }^{11}$ However, the latter are not the only law-enforcing agency to be considered. Let us therefore take a short look at the various hurdles an electric rice cooker has to face before ending up on the shelves of Mrs. Hà's market stall.

Lào Cai small traders obtain their Chinese-produced wares from three main sources: wholesalers and retailers in Hekou, mobile Chinese traders who regularly operate between Hekou and Lào Cai, and Vietnamese transporters and intermediaries. The latter take orders from local retailers and bring the goods across the border for a perpiece or per-load fee. Their net profit from the transaction depends on their negotiation skills with customs officials, which puts those with greater bargaining power and well- established relationships of complicity at a clear advantage. A transporter-intermediary with a load full of Chinese goods stashed into the oversized bags of her pack bike first has to report to the Chinese customs and file a customs declaration stating the total value of the goods. She (or he) then has to pass by the Entry-Exit Inspection and Quarantine officer, who briefly checks whether the load contains quarantine-risk items or prohibited goods. After having her border-crossing permit stamped by the immigration officer, she crosses the bridge and heads toward the Vietnamese customs and immigration office. For the inspection process to go smoothly, she may pay the customs officer a so-called tax of 20,000-30,000 đông (around \$0.95-1.40). ${ }^{12}$ If the officer on duty is easygoing (dễ tính), she may cross the checkpoint without having her load inspected. Dealing with customs officers is thus a risky business fraught with uncertainty because it basically leaves the transporter-intermediary at the mercy of the individual customs officer's whims and demands: whereas one day the officer on duty may let her pass without further hassle, the next day he may feel inclined to conduct a thorough inspection of the goods (see Figure 3). Those who can afford it, like Mr. Hưng, therefore make arrangements with customs officials on a monthly basis, which basically means paying a fee the amount of which is commensurable with the volume of their expected goods traffic.

Another authority to be considered is the market control department (under the Ministry of Trade and Industry) that monitors the enforcement of trade regulations and takes actions against the inflow of illegal goods and counterfeits. Again, the size of the fee depends on the kind and amount of goods carried across the border. A key element of these arrangements is that they create an obligation on part of the recipient to bend or ignore the existing rules to the givers' benefit, thus minimizing (though never completely eliminating) the risk of customs scrutiny. Mr. Hung conceives of this arrangement as an exchange: "They give us a bowl of rice, and we reciprocate them with a bowl of congee" [nguơoi ta cho minh bát cơm, minh bót lại bát cháo cho người ta].

Mr. Hung's elucidation with regard to his bribe arrangements deserves some further attention in light of the concept of the moral economy advanced by E. P. Thompson (1971) in the context of the English working class and applied to Asian peasant societies by James Scott (1976). While Thompson's emphasis was "confined to confrontations in the market-place over access (or entitlement) to 'necessities' - essential food" in times of scarcity (Thompson 1991:337), Scott further underlined the importance of social norms and values that inform notions of rights to just prices (including rents and taxes) and access to economic resources, as well as moral expectations regarding the balance of reciprocity in the relations between common people and ruling elites. Such notions can also be seen at work in the small-scale traders' bribe arrangements. By granting an exception to the restrictions imposed by the law, the state official allows the small trader to import, either tax free or tax reduced, cheap goods that are in popular demand and 


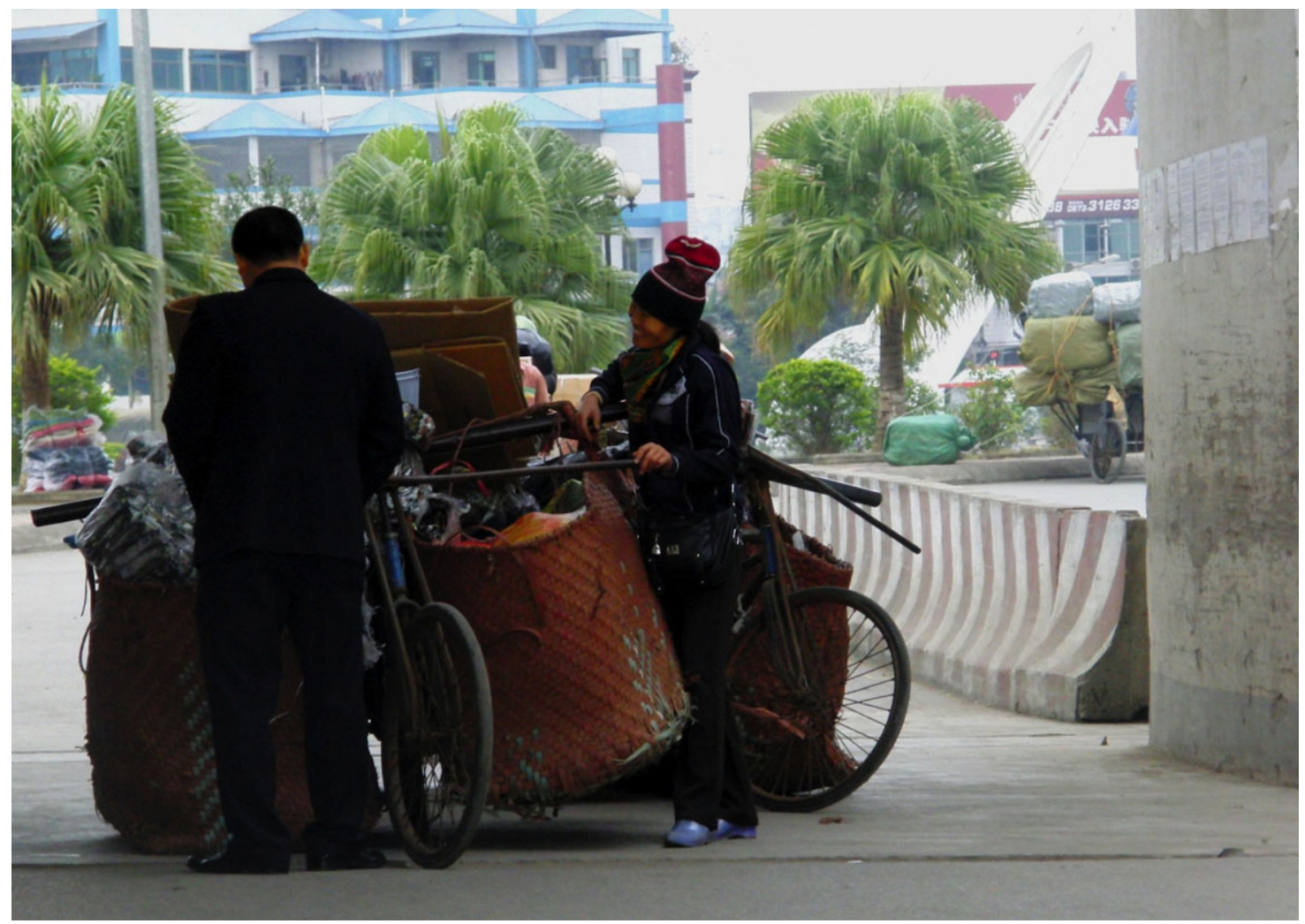

FIGURE 3. A Vietnamese customs official inspects a load of Chinese goods stowed inside the large bags of a transporter's cargo bicycle at the Lào Cai-Hekou international border gate. (Photo by the author, January 2011)

can be sold with a reasonable profit so that the small trader has a bowl of steamed rice to eat. In return for the officer's leniency, the trader presents him with a token of appreciation ("a bowl of rice congee"). Anyone who has prepared cháo knows how little rice is needed for a whole cauldron of congee - although, strictly speaking, the human labor involved in this transformation certainly accounts for some added value - and so the cháo is therefore seen as a fraction of the benefits bestowed.

In addition to its construal as a share of profits, the riceand-congee metaphor serves as a poignant reminder that, according to popular conceptions of virtuous leadership, a state official should be good hearted with the people and act in their interests (Koh 2006:91-95; Malarney 1997). This becomes even more apparent when we look at its flip sidethat is, when a cadre is blamed for filling his own bowls with steamed rice while leaving the common people only with congee. One of the market women recalled an incident when the market vendors requested the market management board carry out urgent repairs. Despite their repeated complaints, the then-director of the management board refused to take action until the case was brought to the attention of the local people's committee. Mrs. Binh, who had been at the forefront of requesting building repairs, recalls how she had phrased her appeal to the market management director: "You [officials] must live in accordance with reason and sentiment [có lý có tình] . . . we labourers provide your children with bowls of rice to eat, so let my children have a bowl of cháo!" (field notes, December 28, 2010). Mrs. Bình's appeal can be viewed as a critique of the immoral behavior of the state official who, rather than acting in the interest of the common people, fills his children's bowls with steamed rice extracted from the toil of small traders who are left with barely enough to feed their offspring with congee.

State policies and legal restrictions imposed on bazaartype forms of economic activity (including taxes, tariffs, trademark rights, quality standards, etc.) are felt by smallscale traders to constrain their participation in the new rules-based economy. Their claims on the state to their right of making a substantial living and filling their bowls with rice instead of cháo are reflected in the ways in which small traders rhetorically cast their petty bribe arrangements with officials as benevolent acts of providing access to economic opportunity for which they offer a token of appreciation - the bribe - in return. This doesn't mean that traders are unaware of the fact that state officials bolster their income quite substantially from all the bowls of cháo they receive. However-and this is important to note - the metaphorical justification of the bribe as a means of the small trader's economic survival, on the one hand, and as an act of the state official's compassion (thông cảm), on the other hand, transforms this type of corrupt exception into a legitimate, and perhaps even moral, practice. 
The popular conceptualization of a virtuous official resonates well with the Confucian-based emphasis on "leadership by moral virtue" (Gillespie 2002:184) that has been adopted (and adapted) by the Communist Party as one of its core principles. The extent to which contemporary state officials take advantage of their positions to enrich themselves, however, has long exceeded the limits of acceptability in the eyes of the public. The law, after all, is not only negotiated by small traders in their own interest. Oftentimes, it also serves as a pretext for the extortion of bribes by corrupt officials. Moreover, many traders are aware that even the most compassionate customs official in fact takes more than is his due share. According to Mr. Dũng, customs officials not only content themselves with the additional income from the small trader's bribe but also siphon off large parts of the tax revenue: "Besides the law-making money (tiên làm luật), 70 percent of the reduced tax rate I pay ends up in the pockets of the customs officers and their patrons. Only about 30 percent go to the state coffer" (field notes, August 30, 2012). Regardless of whether this particular accusation is valid or not, what it implies is that the petty bribe arrangements of Lào Cai small traders are deeply entrenched in the exigencies of systemic corruption and (inevitably) contribute to the sustenance of the corrupt exception as the only viable way of securing access to economic resources and muddling through the vicissitudes of life. Compassion and sentiment are therefore only one side of the coin in the metaphorical construal of their complicit relationships with state officials. The other side - marked by mutual contempt — reveals the arbitrary nature of sovereign power in sites of corrupt exception at the Vietnam-China border to an even greater extent.

\section{PREDATORY HARASSMENT}

Let me illustrate the above with another vignette from my fieldwork. It was a Saturday afternoon in September of 2012. My assistant and I were about to embark on one of our last rounds at Lào Cai market before departing from the field when we noticed a crowd gathering around one of the stalls in the souvenir section. Whereas I decided to stay inconspicuously out of sight, my assistant joined the vendors at one of the nearby stalls from where she could observe the scene and take note of the vendors' comments. As it turned out, Mrs. Linh's stall had been targeted in a police raid seeking to crack down on prohibited goods. It is an open secret at the market that several stallholders in the souvenir section offer so-called hot goods (hàng nóng), such as dangerous weapons or goods that are considered as morally harmful (e.g., adult toys and sexual health products) for sale under the counter, thus risking hefty fines and having their stalls closed down for several weeks if caught red-handed (see Figure 4).

Earlier that day, two separate teams of plainclothes police had acted as customers and bought several electroshock weapons and sex toys for a total market value of eight mil- lion đồng (around \$380). At the time of our arrival at the market, the stall had already been thoroughly searched, and a number of guns, knives, and tasers, as well as a bunch of vibrators and blow-up dolls, had been confiscated. Two officers of the market control department took record of the case, while the vendors at the neighboring stall engaged in discussion. "Everyone [in this section] sells that stuff, there ain't anyone who doesn't," one of them claimed. "It's just bad luck that these cunt-faced bastards came by [Linh's stall]. These dogs just crave money!” Meanwhile, Mrs. Linh was pleading with the market control officer, "I have to take care of my family, we're not making much money, please kindly exempt me [from being fined]!” A small group of vendors, including those who are most notorious for selling prohibited items, was watching from afar. "It doesn't help to call on your family members [who work for the government] or on police acquaintances," one of them argued. "You still have to pay, probably 25-30 million đồng [\$1190-\$1430]. If you're lucky, they close your stall for only a few days; if not, they shut it down for a whole two weeks, then it'll be long before you can earn some rice to eat!” Mrs. Linh's friend at the opposite stall added, "These dogs just want to eat money (ăn tiền), go ahead and make law with them to get over with it."

The following day Mrs. Linh's stall remained closed. My assistant learned from one of the market women that the ward police had played hard and threatened that from now on they would raid one suspected vendor's stall every day. To prevent this from happening in the future, the stallholders in question all went to the ward police station and paid three million đồng each (\$143), true to the common wisdom that "upfront money is clever money" [ đồng tiền đi trước là đồng tiền khôn]. Unlike a similar case at the beginning of the new lunar year in 2012, the raid of Mrs. Linh's stall went unreported in the local press.

The police raid incident is in many ways similar to the quality inspection related previously: a law-enforcing authority sets an example by singling out a particular stall for scrutiny, which then leads to negotiations of a fee for being exempted from such inspections for a while - albeit there is no guarantee of how long the exemption will last. Such raids are thus generally understood as a staged pretext for bribe arrangements and are met with much resentment and contempt on the part of the small traders. But whereas in the case of Mrs. Hà's substandard rice cookers the inspection was construed as a kind reminder of state authority ("The annual inspection is just to remind you that there in fact is a law"), the raid for weapons and sex toys at Mrs. Linh's stall serves as a crude assertion of sovereign power to clamp down on the souvenir vendors' illegal trade in prohibited goods any day, at any time. Rather than being seen as legitimate enforcers of law, the police (as well as other law-enforcing officials) are despised as hungry predators who literally feed on money (ăn tiên) — despite the fact that dealing in prohibited items, particularly deadly weapons, does not render the perpetrators as morally virtuous 


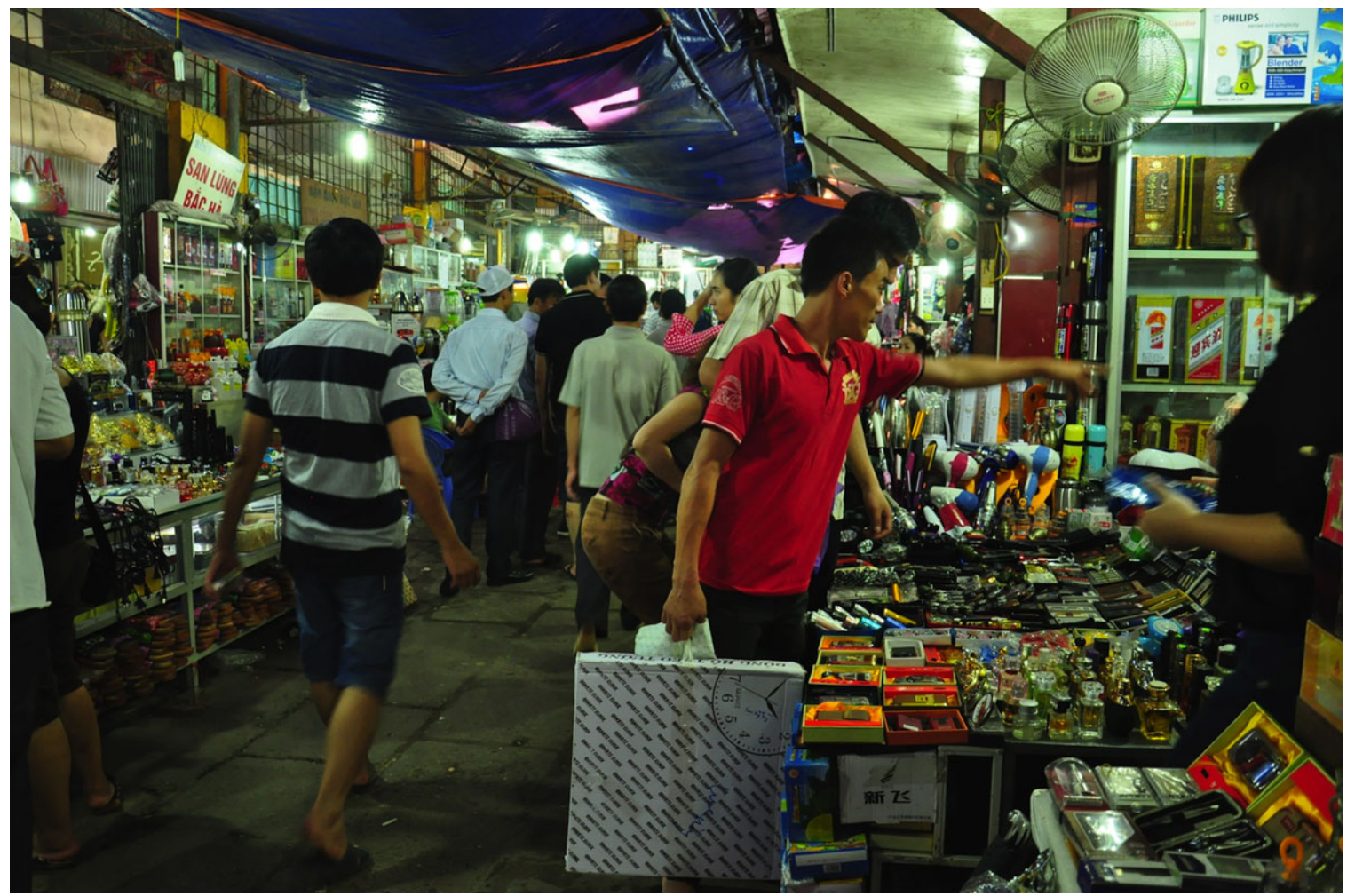

FIGURE 4. The souvenir section of Lào Cai Market is mainly patronized by Chinese and Vietnamese tourists. Besides small souvenirs, liquor, and cigarettes, some vendors also have prohibited items on offer under the counter. (Photo by the author, September 2012)

subjects either. ${ }^{13}$ Of course, the profits from selling an electric taser to a teenage hoodlum are significantly higher than from vending rice cookers and other electric household appliances, and so are the sums that need to be paid for this gate to riches to remain open on both sides. Law making - in its euphemistic sense of demanding or negotiating bribeshere basically emerges as the negotiation of the very terms that facilitate a corrupt state of exception, defined by the murky entanglements among the shadow economy, criminal networks, and the state, of which the petty bribe arrangements between small traders and local-level state officials obviously constitute not more than a negligible fraction.

Whereas vendors of illicit items earn quite substantially and are usually able to quickly recover their costs of corrupt payments and loss of earnings, small-scale traders at the bottom level of the Vietnamese market hierarchy are more vulnerable to the violent aspects of localized sovereign power. This applies particularly to the street vendors who sell their merchandise on the pavement outside the market. Although street vendors in Lào Cai City are officially banned from selling in that area between 6:00 a.m. and 6:00 p.m., they are commonly tolerated during this time - at least in the sense that they are not chased away on a regular basis. However, in addition to periodic raids carried out by the police unit in charge of public order in the city (đội trật tự đô thị), street vendors suffer various types of harassment, such as demands for bribes, intimidation, threads, and outright theft. ${ }^{14}$ It is in these violent instances of the corrupt exception that we can most clearly discern the shadowy appearance of Agamben's homo sacer, "the one-time citizen rendered outlaw who has no recourse to law other than that of the sovereign's power over his life and death" (Downey 2009:111)_or, at the Vietnam-China border, over the small-scale traders' bowls of rice or congee.

\section{CONCLUSION}

In Vietnam's postreform era, the proliferation of (unevenly distributed) profiteering opportunities have, in addition to creating new forms of corruption, transmuted previously prevailing types of corrupt acts in multiple ways across different levels of state-society relations. Since the VietnamChina border reopened for trade in the early 1990s, a plethora of laws, bylaws, decrees, and circulars has been issued to control and regulate the cross-border trade flow of Chinese goods. Alongside the ever-growing number of regulatory provisions and requirements, the Lào CaiHekou international border gate transformed into a lucrative post that provides law-enforcement officials with plenty of extra income from granting exceptions in exchange for bribes.

Starting from the metaphorical framing of petty corruption in the context of small-scale trade at the VietnamChina border as "making law," I have conceived of bribery arrangements between Kinh (ethnic majority) traders and local state officials in terms of a corrupt exception - that is, as a 
condition of localized sovereign power in which the rule of law has no force and corrupt acts and practices acquire the force of law (cf. Agamben 2005:39). The incidents I have described illustrate that the prevalent stigma of moral inferiority, fraudulence, and dishonesty attached to market trade plays a decisive role in the small traders' self-descriptions as low-profit earners whose shelves are glutted with unsalable goods. Notions of family responsibility and images of nurturing are cleverly employed to urge local officials to show compassion and apply the law with reason and sentiment, in flexible and selective ways. Moreover, the riceand-congee-metaphor adds a strong moral dimension to small traders' bribe arrangements by casting the latter in a terminology of reciprocal obligation in which the bribe is construed as a token of appreciation in exchange for reduced tariffs on their import. "If we don't make law," Mr. Hưng explains, "they charge higher import taxes. If we make law, they may let us pass through right away. It's all just a give and take" (conversation with author, August 27, 2012).

The analysis of the "popular semiology of corruption" (Blundo and Olivier de Sardan 2006) sheds light on how Vietnamese cross-border traders perceive and experience a state that Martin Gainsborough (2010:182) has described as "little more than a disparate group of actors with a weak notion of 'the public good,' using uncertainty, not impartial rules, as the basis of order." It also reveals how the corrupt exception is engaged to both contest and reinforce local sovereign power. On the one hand, the rhetorical construction of bribed state officials as compassionate accomplices serving the interests of the people can be understood as a (somewhat ironic) reminder that moral (and legitimate) leadership must rest on the devotion to the sustenance and well-being of the ruled not on the use or extraction of resources for the benefit of the rulers. On the other hand, such arrangements are considered essential in the obvious sense that they are felt to create better profit opportunities from small-scale trade.

In common with Ong's (2006) spaces of neoliberal exception - that is, economic enclaves and special administrative zones that are subject to different modes of regulation than the rest of the country to mobilize economic resources - the corrupt exception creates avenues for economic self-advancement for otherwise disadvantaged smalltrader and migrant citizens in the Vietnam-China border region that the existing legal framework restricts in scale and scope. The difference, of course, is that these avenues are not officially sanctioned. One may perhaps argue that they are not particularly discouraged either. Many governments, in fact, evade rigor in enforcing tax and tariff laws as a way of ensuring their perceived legitimacy and the loyalty of their subjects (Karras 2010:109). In any case, and irrespective of whether their merchandise is strictly prohibited by law or merely liable to customs duty, the corrupt exception pushes cross-border traders into a de facto illegality wherein they remain subjected to arbitrary lawmaking and excluded from legal protection. Considered in this way, the corrupt exception seems to be nestling in a shadowy overlap between what Ong (2006) describes as neoliberalism as exception and exception to neoliberalism. At the Lào Cai-Hekou border gate, its complicit construal as a compassionate act of mutual feeding thus underscores the failure of the central party state to provide better livelihood opportunities for its citizens as much as it reinforces the exercise of assumed sovereign power in a permanent state of corrupt exception in which "law" is "made" in exchange for bribes.

Kirsten W. Endres Department "Resilience and Transformation in Eurasia," Max Planck Institute for Social Anthropology, 06114 Halle/Saale, Germany; endres@eth.mpg.de; http://www.eth.mpg.de

\section{NOTES}

Acknowledgments. This research took place in the frame of a cooperative agreement between the Max Planck Institute for Social Anthropology and the Vietnamese Academy of Social Sciences in Hanoi. I am indebted to traders at Lào Cai market for generously sharing their time and their stories and to research assistants and colleagues in Vietnam for their commitment and discussions. Special thanks go to Regina Abrami, Keebet von Benda-Beckmann, Christine Bonnin, James Carrier, Chris Hann, Gustav Peebles, Minh Nguyen, Oliver Tappe, Sarah Turner, and students at the University of Halle-Wittenberg for valuable comments on earlier drafts and presentations. Tom Boellstorff, Michael Chibnik, and four anonymous $A A$ reviewers provided detailed and insightful suggestions for further improvement, which are deeply appreciated. Thanks also go to Jutta Turner for preparing the map and to Soledad Jiménez Tovar for the Spanish abstract translation.

1. For a concise discussion of whether and in what ways Vietnam can be considered as neoliberal, see the special issue of Positions edited by Schwenkel and Leshkowich (2012).

2. Since Vietnam passed its first anticorruption law in 2005, there has been a marked increase in high-profile corruption, fraud, and embezzlement charges resulting in long-term imprisonment and death penalty sentences (Gainsborough 2010; Hayton 2010; MacLean 2012). This clampdown should not be attributed solely to an intensification of anticorruption measures, as Gainsborough (2010:52) cautions. These big cases, he argues, "are best understood as an attempt by the political centre to discipline the lower levels of the party-state in a climate of increased decentralization."

3. Vietnam's active blogosphere and social media networks have over the past years contributed significantly to raising the public's awareness of the systemic nature of corruption. Some of the most biting accusations are even assumed to be put forward by rival factions within the Communist Party.

4. In Soviet Russia and prereform China, such personal networks constituted by the exchange of favors (known as blat and guanxi) played a similar role in securing access to scarce resources (e.g., Ledeneva 1998; Yang 1994). 
5. This also applies to postsocialist transition economies, wherein "insider political-business networks with inside information routinely privatized for themselves entire swaths of theretofore state resources and enterprises at fire-sale prices" (Wedel 2012:465).

6. It seems tempting to probe into various shades of meanings with regard to the word lam (work, labor, do, make, pretend, use as). Doing so, however, runs the risk of pushing speculation over the hidden meanings of làm luạt too far, particularly because the term also applies to proper, legal processes of law making.

7. Although upland ethnic minority groups account for the majority of the overall population in the province, Lào Cai City (as well as most district towns) is now overwhelmingly dominated by Kinh lowlanders. Female traders dominate the markets (as they do in Vietnam as a whole), but male traders are not exceptional and can be found in almost every market section (for a concise discussion of the co-construction of gender and class among Bến Thành market traders in Ho Chi Minh City, see Leshkowich 2011). Ethnic minority cross-border traders, in contrast, are prevalent at national-level crossings (where Chinese and Vietnamese citizens may cross with a visa or permit), as well as at so-called supplementary crossings, usually in remote areas where borderland residents are the only ones who are allowed to traverse the border and foreigners are not allowed to linger without special permits (for more on upland ethnic minority trade, see Bonnin 2011; Turner 2010; Schoenberger and Turner 2008).

8. Yuk Wah Chan's study of Vietnamese-Chinese relationships in the postreform era provides further insights into the dynamics of transborder interactions between Vietnamese and Chinese nationals (Chan 2013).

9. To build trust with my informants, I did not tape conversations and instead relied on the priceless ability of my assistant to render the narrations of our interlocutors very close to their original wording. I thus do not refer to the transcription of recorded speech when I present statements in quotation marks but, rather, to detailed field notes taken after each encounter.

10. The monthly income of stallholders in the market averages between five and fifteen million đồng (around \$240-\$700 in 2012). Despite seasonal fluctuations in trading profits, most of them actually see their income as "fairly sufficient."

11. As Leshkowich (2008) has pointed out, the performance of weakness in the context of dealing with state officials is also profoundly gendered. Kusakabe (2009) made a similar point with regard to women traders using gender stereotypes in negotiating with officials at the Thai-Lao border.

12. Porters and trader intermediaries earn an average 100.000 đồng per day (around \$5). "Fees" paid at the border gate cut into their net profits because the responsibility for customs clearance rests on their shoulders. Their income therefore depends not only on the quantities they carry but also on their skills in negotiating with customs officials.

13. The sale of prohibited items was something about which I was not supposed to know. From what my assistant gleaned through gossip at the market, however, I conclude that this is an extremely lucrative — albeit risky — business. Souvenir vendors who do not engage in selling these items generally talk badly about those who do, citing the harmfulness of deadly weapons, especially if sold to young criminals, and the danger of being caught as main reasons for abstaining from it.

14. Unlike in India or the Philippines, restrictions on the formation of associations persist and effectively block possible avenues for Vietnamese street vendors to pursue and safeguard their interests (cf. Anjaria 2011; Milgram 2011).

\section{REFERENCES CITED}

Abrami, Regina M.

2002 Just a Peasant: Economy and Legacy in Northern Vietnam. In Post-Socialist Peasant? Rural and Urban Constructions of Identity in Eastern Europe, East Asia and the Former Soviet Union. Pamela Leonard and Deema Kaneff, eds. Pp. 94-116. Basingstoke: Palgrave.

Agamben, Giorgio

1995 Homo Sacer: Sovereign Power and Bare Life. Meridian: Crossing Aesthetics Series. Daniel Heller-Roazen, trans. Stanford: Stanford University Press.

2005 State of Exception. Kevin Attell, trans. Chicago: The University of Chicago Press.

Anders, Gerhard, and Monique Nuijten

2007 Corruption and the Secret of Law: An Introduction. In Corruption and the Secret of Law: A Legal Anthropological Perspective. Monique Nuijten and Gerhard Anders, eds. Pp. 1-24. Aldershot: Ashgate.

Anjaria, Jonathan Shapiro

2011 Ordinary States: Everyday Corruption and the Politics of Space in Mumbai. American Ethnologist 38(1):58 72 .

Ben-Amos, Dan

1999 Metaphor. Journal of Linguistic Anthropology 9(1-2):152154.

Blundo, Giorgio, and Jean-Pierre Olivier de Sardan

2006 The Popular Semiology of Corruption. In Everyday Corruption and the State: Citizens and Public Officials in Africa.

Giorgio Blundo and Jean-Pierre Olivier de Sardan, eds. Pp.

110-134. London: Zed.

Bonnin, Christine

2011 Markets in the Mountains: Upland Trade-Scapes, Trader Livelihoods, and State Development Agendas in Northern Vietnam. PhD dissertation, Department of Geography, McGill University, Montreal, Canada.

Brown, Ed, and Jonathan Cloke

2004 Neoliberal Reform, Governance and Corruption in the South: Assessing the International Anti-Corruption Crusade. Antipode 36(2):272-294.

Bruns, Bettina, and Judith Miggelbrink, eds.

2012 Subverting Borders: Doing Research on Smuggling and Small-Scale Trade. Wiesbaden: Springer.

Chalfin, Brenda

2008 Sovereigns and Citizens in Close Encounter: Airport Anthropology and Customs Regimes in Neoliberal Ghana. American Ethnologist 35(4):519538. 
Chan, Yuk Wah

2013 Vietnamese-Chinese Relationships at the Borderlands: Trade, Tourism and Cultural Politics. Oxon: Routledge.

Comaroff, John L., and Jean Comaroff

2006 Law and Disorder in the Postcolony: An Introduction. In Law and Disorder in the Postcolony. Jean Comaroff and John L. Comaroff, eds. Pp. 1-56. Chicago: University of Chicago Press.

Dang, Phong, and Melanie Beresford

1998 Authority Relations and Economic Decision-Making in Vietnam: An Historical Perspective. Copenhagen: Nordic Institute of Asian Studies.

Donnan, Hastings, and Thomas M. Wilson

1999 Borders: Frontiers of Identity, Nation and State. Oxford: Berg.

Downey, Anthony

2009 Zones of Indistinction: Giorgio Agamben's "Bare Life” and the Politics of Aesthetics. Third Text 23(2):109-125.

Gainsborough, Martin

2010 Vietnam: Rethinking the State. London: Zed; Chiang Mai: Silkworm.

Galemba, Rebecca B.

2012 "Corn Is Food, Not Contraband": The Right to "Free Trade" at the Mexico-Guatemala Border. American Ethnologist 39(4):716-734.

Gillespie, John

2001 Self-Interest and Ideology: Bureaucratic Corruption in Vietnam. Asian Law Journal 3(1):1-36.

2002 The Political-Legal Culture of Anti-Corruption Reforms in Vietnam. In Corruption in Asia: Rethinking the Governance Paradigm. Tim Lindsey and Howard Dick, eds. Pp. 167-200. Annandale: Federation.

2008 Localizing Global Rules: Public Participation in Lawmaking in Vietnam. Law and Social Inquiry 33(3):673-707.

2009 Testing the Limits to the "Rule of Law": Commercial Regulation in Vietnam. The Journal of Comparative Asian Development 8(2):245-272.

Gupta, Akhil

2005 Narrating the State of Corruption. In Corruption: Anthropological Perspectives. Dieter Haller and Cris Shore, eds. Pp. 173-193. Anthropology, Culture, and Society series. London: Pluto.

Harms, Erik

2012 Beauty as Control in the New Saigon: Eviction, New Urban Zones, and Atomized Dissent in a Southeast Asian City. American Ethnologist 39(4):735750 .

Hayton, Bill

2010 Vietnam: Rising Dragon. New Haven: Yale University Press. Herzfeld, Michael

2005 Cultural Intimacy: Social Poetics in the Nation-State. New York: Routledge.

Karras, Alan L.

2010 Smuggling: Contraband and Corruption in World History. Exploring World History Series. Lanham: Rowman and Littlefield.
Kerkvliet, Benedict J. Tria

2005 The Power of Everyday Politics: How Vietnamese Peasants Transformed National Policy. Ithaca: Cornell University Press.

Koh, David W. H.

2006 Wards of Hanoi. Singapore: Institute of Southeast Asian Studies.

Kusakabe, Kyoko

2009 The Politics of "Opening Up": Female Traders on the Borderlands of Cambodia, Laos, Thailand, and Burma (Myanmar). In On the Borders of State Power: Frontiers in the Greater Mekong Sub-Region. Martin Gainsborough, ed. Pp. 60-74. Routledge Studies in the Modern History of Asia. London: Routledge.

Lakoff, George, and Mark Johnson

1980 Metaphors We Live By. Chicago: University of Chicago Press.

Ledeneva, Alena V.

1998 Russia's Economy of Favours: Blat, Networking, and Informal Exchange. Cambridge Russian, Soviet and PostSoviet Studies, 102. Cambridge: Cambridge University Press.

Leshkowich, Ann Marie

2008 Wandering Ghosts of Late Socialism: Conflict, Metaphor, and Memory in a Southern Vietnamese Marketplace. The Journal of Asian Studies 67(1):5-41.

2011 Making Class and Gender: (Market) Socialist Enframing of Traders in Ho Chi Minh City. American Anthropologist 113(2):277-290.

Lü, Xiaobo

2000 Cadres and Corruption: The Organizational Involution of the Chinese Communist Party. Stanford: Stanford University Press.

MacGaffey, Janet, Vwakyanakazi Mukohya, Rukarangira wa Nkera, Brooke Grundfest Schoepf, Makwala ma Mavambu ye Beda, and Walu Engundu

1991 The Real Economy of Zaire: The Contribution of Smuggling and Other Unofficial Activities to National Wealth. London: James Currey; Philadelphia: University of Pennsylvania Press.

MacLean, Ken

2008 The Rehabilitation of an Uncomfortable Past: Everyday Life in Vietnam during the Subsidy Period (1975-1986). History and Anthropology 19(3):281-303.

2012 Enacting Anticorruption: The Reconfiguration of Audit Regimes in Contemporary Vietnam. Positions: Asia Critique 20(2):595-625.

Malarney, Shaun Kingsley

1997 Culture, Virtue, and Political Transformation in Contemporary Northern Viet Nam. The Journal of Asian Studies 56(4):899-920.

1998 State Stigma, Family Prestige, and the Development of Commerce in the Red River Delta of Vietnam. In Market Cultures: Society and Morality in the New Asian Capitalisms. Robert W. Hefner, ed. Pp. 268-289. Boulder: Westview.

Milgram, Lynne B. 
2011 Reconfiguring Space, Mobilizing Livelihood: Street Vending, Legality, and Work in the Philippines. Journal of Developing Societies 27(3-4):261-293.

Ong, Aihwa

2006 Neoliberalism as Exception: Mutations in Citizenship and Sovereignty. Durham: Duke University Press.

Rigi, Jakob

2012 The Corrupt State of Exception: Agamben in the Light of Putin. Social Analysis 56(3):69-88.

Schoenberger, Laura, and Sarah Turner

2008 Negotiating Remote Borderland Access: Small-Scale Trade on the Vietnam-China Border. Development and Change 39(4):667-696.

Schwenkel, Christina, and Ann Marie Leshkowich, eds.

2012. Guest Editors' Introduction: How Is Neoliberalism Good to Think Vietnam? How Is Vietnam Good to Think Neoliberalism?. Positions 20(2):380-401.

Scott, James C.

1976 The Moral Economy of the Peasant: Rebellion and Subsistence in Southeast Asia. New Haven: Yale University Press.

Shore, Cris, and Dieter Haller

2005 Introduction - Sharp Practice: Anthropology and the Study of Corruption. In Corruption: Anthropological Perspectives. Dieter Haller and Cris Shore, eds. Pp. 1-26. London: Pluto.

Sikor, Thomas, and Phuc Xuan To

2011 Illegal Logging in Vietnam: Lam Tac (Forest Hijackers) in Practice and Talk. Society and Natural Resources 24(7):688701.

Smith, Daniel Jordan

2007 A Culture of Corruption: Everyday Deception and Popular Discontent in Nigeria. Princeton: Princeton University Press. Steinmüller, Hans

2010 Communities of Complicity: Notes on State Formation and Local Solidarity in Rural China. American Ethnologist 37(3):539-549.
Sun, Yan

2004 Corruption and Market in Contemporary China. Ithaca: Cornell University Press.

Thompson, Edward P.

1971 The Moral Economy of the English Crowd in the Eighteenth Century. Past and Present 50:76-136.

1991 Customs in Common: Studies in Traditional Popular Culture. New York: The New Press.

Titeca, Kristof, and Tom de Herdt

2010 Regulation, Cross-Border Trade and Practical Norms in West Nile, North-Western Uganda. Africa 80(4):573594.

Turner, Sarah

2010 Borderlands and Border Narratives: A Longitudinal Study of Challenges and Opportunities for Local Traders Shaped by the Sino-Vietnamese Border. Journal of Global History 5(2):265287.

Wagner, Mathias

2011 Die schmugglergesellschaft: Informelle ökonomien an der ostgrenze der Europäischen Union, eine ethnographie [The smuggler society: Informal economies at the eastern border of the European Union, an ethnography]. Bielefeld: transcript.

Walker, Andrew

1999 The Legend of the Golden Boat: Regulation, Trade and Traders in the Borderlands of Laos, Thailand, China and Burma. Anthropology of Asia Series. Honolulu: University of Hawai'i Press.

Wedel, Janine R.

2012 Rethinking Corruption in an Age of Ambiguity. Annual Review of Law and Social Science 8:453-498.

Yang, Mayfair Mei-hui

1994 Gifts, Favors, and Banquets: The Art of Social Relationships in China. The Wilder House Series in Politics, History, and Culture. Ithaca: Cornell University Press. 